\title{
Health and socioeconomic impact of work-related asthma
}

\author{
O. Vandenplas*, K. Toren", P.D. Blanc ${ }^{*}$
}

Health and socioeconomic impact of work-related asthma. O. Vandenplas, K. Toren, P.D. Blanc. (C) ERS Journals Ltd 2003.

ABSTRACT: There is accumulating evidence that the workplace environment contributes significantly to the general burden of asthma. The purpose of this review is to explore the respiratory health and socioeconomic consequences of work-related asthma by addressing a series of controversial issues: 1) what is the natural history of occupational asthma and in what ways does ongoing exposure to the causal agent impact clinical outcomes?; 2) how does the natural history of irritant-induced asthma differ in its health outcomes from immunologically-mediated occupational asthma?; 3) do working conditions have a significant impact on asthma regardless of the aetiology of the disease?; 4) what is the scope of work disability from work-related-asthma in social and economic terms?; 5) what is the clinician's role in reducing the respiratory health consequences of work-related asthma? 6) to what extent do existing compensation and other social insurance schemes successfully address occupational asthma and workaggravated asthma?

Eur Respir J 2003; 22: 689-697.
*Service de Pneumologie, Cliniques de MontGodinne, Université Catholique de Louvain, Yvoir, Belgium. "Dept of Respiratory Medicine and Allergology and Dept of Occupational and Environmental Medicine, Sahlgrenska University Hospital, Göteborg, Sweden. "Division of Occupational and Environmental Medicine, Dept of Medicine, University of California, San Francisco, California, USA.

Correspondence: O. Vandenplas, Service de Pneumologie, Cliniques universitaires UCL de Mont-Godinne, B-5530 Yvoir, Belgium. Fax: 3281423352

E-mail: olivier.vandenplas@pneu.ucl.ac.be

Keywords: Asthma, disability, occupational disease

Received: May 132003

Accepted: May 142003

O. Vandenplas is supported by the Services Fédéraux des Affaires Scientifiques, Techniques et Culturelles (grant SSTC PS/10/44).
Asthma represents a considerable source of morbidity and economic burden [1, 2]. The workplace environment can initiate or trigger asthma and result in the development of different types of work-related asthma, among these the following conditions can be distinguished: 1) immunological occupational asthma (OA) induced by a variety of high and low molecular weight sensitising agents; 2) irritant-induced asthma (or "nonimmunological OA") resulting from the persistent effects of single or multiple exposures to high concentrations of irritant substances; and 3) work-aggravated asthma symptoms in workers with pre-existing or coincident asthma [3, 4]. Epidemiological surveys indicate that occupational exposures could account for $\sim 10-15 \%$ of adult asthma and could contribute significantly to the cost of asthma [5]. This review will address a series of issues relating to the health and economic consequences of the different forms of work-related asthma.

\section{What is the natural history of occupational asthma and in what ways does ongoing exposure to the causal agent impact clinical outcomes?}

Follow-up studies of workers with immunological OA have shown that avoidance of exposure to the causative agent results in a significant improvement in asthma symptoms, airway obstruction, and nonspecific bronchial hyperresponsiveness (NSBH). Nonetheless, removal from exposure does not necessarily lead to complete recovery from asthma. Approximately $70 \%$ of affected workers still experience asthma symptoms and retain NSBH several years after cessation of the offending exposure [6-21]. NSBH can, however, further improve $>5$ yrs after exposure cessation [18]. Persistence of asthma has been consistently associated with a longer duration of work-related symptoms before removal and with a more severe asthma at the time of diagnosis [9-18, $21,22]$. Atopy and tobacco smoking have not been identified as significant determinants of outcomes in OA.

The long-term health effects of reducing rather than eliminating exposure to the agent causing OA remain uncertain. Reduction of exposure can be achieved through relocation to less exposed jobs, improvement in workplace hygiene, modifying materials to reduce their allergenic properties, and use of personal protective devices. Shortterm studies indicate that latex gloves with a lower allergen content [23, 24] and helmet respirators [24-28] can reduce asthmatic reactions in subjects with OA. A number of studies have compared the long-term outcome of subjects who reduce exposure with those who completely avoid further exposure

Previous articles in this series: No. 1: Vandenplas O, Malo J-L. Definitions and types of work-related asthma: a nosological approach. Eur Respir J 2003; 21: 706-712. No. 2: Moscato G, Malo J-L, Bernstein D. Diagnosing occupational asthma: how, how much, how far? Eur Respir J 2003; 21 : 879-885. No. 3: Mapp CE. The role of genetic factors in occupational asthma. Eur Respir J 2003; 22: 173-178. No. 4: Sastre J, Vandenplas O, Park H-S. Pathogenesis of occupational asthma. Eur Respir J 2003; 22: 364-373. No. 5: Gautrin D, Newman-Taylor AJ, Nordman H, Malo J-L. Controversies in epidemiology of occupational asthma. Eur Respir $J$ 2003; 22: 551-559. 
Table 1.-Comparison of asthma severity after cessation or reduction of exposure to the causative agent

\begin{tabular}{|c|c|c|c|c|c|c|}
\hline Causative agent & $\begin{array}{l}\text { Persistence of } \\
\text { symptoms }\end{array}$ & $\begin{array}{l}\text { Persistence } \\
\text { of NSBH }\end{array}$ & $\begin{array}{l}\text { Improvement } \\
\text { of asthma }\end{array}$ & $\begin{array}{l}\text { Worsening } \\
\text { of asthma }\end{array}$ & 1st author [ref no.] & $\begin{array}{c}\text { Year of } \\
\text { study }\end{array}$ \\
\hline \multicolumn{7}{|c|}{ Cessation of exposure } \\
\hline Colophony & $16 / 20$ & $3 / 7$ & $5 / 7$ & $0 / 7$ & BURGE [7] & 1982 \\
\hline Isocyanates & $10 / 20$ & $9 / 12$ & $10 / 20$ & $6 / 20$ & ROSENBERG [9] & 1987 \\
\hline Isocyanates & $31 / 43$ & $31 / 43$ & $22 / 43$ & $5 / 43$ & PISATI [11] & 1993 \\
\hline Isocyanates & NA & $6 / 9$ & $3 / 9$ & $0 / 9$ & PAGGIARO [12] & 1993 \\
\hline Red cedar & $37 / 75$ & $25 / 33$ & $20 / 33$ & $4 / 33$ & CHAN-YEUNG [14] & 1982 \\
\hline Latex & $13 / 16$ & $16 / 16$ & $8 / 16$ & $1 / 16$ & VANDENPLAS [15] & 2002 \\
\hline Total & $107 / 174(61)$ & $90 / 120(75)$ & 68/128 (53) & 16/128 (12) & & \\
\hline \multicolumn{7}{|c|}{ Reduction of exposure } \\
\hline Colophony & $5 / 8$ & $4 / 4$ & $1 / 4$ & $0 / 4$ & BURGE [7] & 1982 \\
\hline Isocyanates & $7 / 7$ & $7 / 7$ & $4 / 7$ & $0 / 7$ & ROSENBERG [9] & 1987 \\
\hline Isocyanates & $17 / 17$ & $17 / 17$ & $0 / 17$ & $13 / 17$ & PISATI [11] & 1993 \\
\hline Isocyanates & NA & $4 / 7$ & $3 / 7$ & $0 / 7$ & PAGGIARO [12] & 1993 \\
\hline Red cedar & $50 / 50$ & $22 / 22$ & $0 / 22$ & $9 / 22$ & CHAN-YEUNG [14] & 1982 \\
\hline Latex & $16 / 20$ & $19 / 20$ & $15 / 20$ & $0 / 20$ & VANDENPLAS [15] & 2002 \\
\hline Total & 95/102 (93) & 73/77 (95) & 23/77 (30) & 22/77 (28) & & \\
\hline
\end{tabular}

Data are presented as number of subjects with outcome variable/number of subjects studied, data in the totals rows are presented as number of subjects with outcome variable/number of subjects studied (\% with outcome variable). NA: data not available; NSBH: nonspecific bronchial hyperresponsiveness; ${ }^{\#}$ : improvement and worsening of asthma assessed on changes in symptoms and/or medication [9], NSBH [7, 12, 14, 15], or a combination of symptoms, spirometry, and NSBH [11].

(table 1) $[7,9,11,12,14,15]$. Pooled analysis of these studies indicates that reducing exposure is more frequently associated with persistence of asthma symptoms (93\%) and NSBH $(95 \%)$, and with worsening of asthma $(28 \%)$ than complete removal $(61 \%, 75 \%$, and $12 \%$, respectively).

Exposure to the causative agent can lead to severe asthmatic reactions in subjects with $\mathrm{OA}$, although deaths due to status asthmaticus following workplace exposure appear to be rare [29]. Data from the Ontario Workers' Compensation Board indicate that the rates of hospitalisation for respiratory disease and mortality among subjects compensated for OA are similar to those observed in asthmatic subjects without work-related asthma [30, 31].

\section{How does the natural history of irritant-induced asthma differ in its health outcomes from immunologically- mediated occupational asthma?}

A valuable series of case reports have provided convincing evidence that a single massive inhalation of a variety of irritant substances can induce the rapid onset of asthma in previously asymptomatic individuals [32-35]. Since the original description of this clinical entity under the term of "reactive airways dysfunction syndrome" or RADS by BROOKS et al. [32], the more inclusive concept of "irritantinduced asthma" arising from single or multiple exposures to high levels of irritants has gained wide acceptance [36, 37]. The pattern of initiation of irritant-induced asthma most strongly supports a primary role for acute or repeated toxic injury of the bronchial epithelium, although the pathophysiological mechanisms leading to the development and persistence of asthma and NSBH remain largely speculative $[33,34]$. Relative risks for initiation, progression, or resolution of irritant-induced asthma have been difficult to ascertain. In recent years limited population-based data have begun to emerge that may be able to shed light on the development of irritant-induced asthma after acute exposure to respiratory irritants. Data from a USA poison control centre suggest an incidence figure of $6 \%$ for respiratory symptoms lasting $\geqslant 2$ weeks following irritant exposures [38]. Pre-existing lung disorders and cigarette smoking were the only significant risk factors for persistent symptoms. The
Surveillance of Work-related and Occupational Respiratory Disease (SWORD) surveillance program in the UK found that inhalation accidents resulted in the development of RADS in $8.5 \%$ of the subjects (i.e. $33 \%$ of the subjects with symptoms persisting for $\geqslant 1$ month [39].

Case reports, as well as compensation-related and other site-specific clinical referral series are likely to skew available data to greater disease severity. Studies of chemical accidents in which groups of subjects are transiently exposed to high concentrations of airway irritants in the community or workplace indicate that airway obstruction persists in a substantial, although highly variable, proportion (ranging from $10-60 \%$ ) of subjects with RADS-like symptoms who have been evaluated from 3 months to 13 yrs after the inciting event [40-45]. Several cohort studies have examined the presence of NSBH following high-level exposure to irritants [42-44, 46-51] (table 2). In most of these studies [42, 44, 46-48] however, it cannot be formally established that NSBH was initiated by irritant exposure, since the level of nonspecific airway responsiveness was not assessed before the offending incident. Few cohort studies have assessed the time course of changes in NSBH after inhalation incidents. BLANC et al. [47] studied 10 of 45 subjects within 2 weeks after an irritant exposure reported to a poison control centre. Eight subjects demonstrated NSBH, while none had airway obstruction. Three months later, NSBH had reversed in only one subject. A cohort of construction workers who had been repeatedly exposed to chlorine over a 3-month period at a pulp mill have been surveyed prospectively [48, 49]. At the initial investigation carried out 18-24 months after the end of exposure, NSBH was found in $29(41 \%)$ of 71 symptomatic workers considered at risk of developing RADS [48]. On subsequent evaluation of these 29 workers 1 yr later ( 30 to 36 months after exposure), NSBH persisted in 14 of 19 subjects who underwent repeated methacholine challenge [49]. Six subjects showed a significant improvement in NSBH, including five subjects whose level of airway responsiveness was no longer in the asthmatic range. Improvement in NSBH was not influenced by smoking habits, atopic status, or treatment with inhaled steroids. During a $4 \mathrm{yr}$ prospective survey of 278 workers in a metal production plant [52, 53], 13 workers presented to the first aid unit with transient respiratory symptoms after accidental inhalation of chlorine [50]. Only 


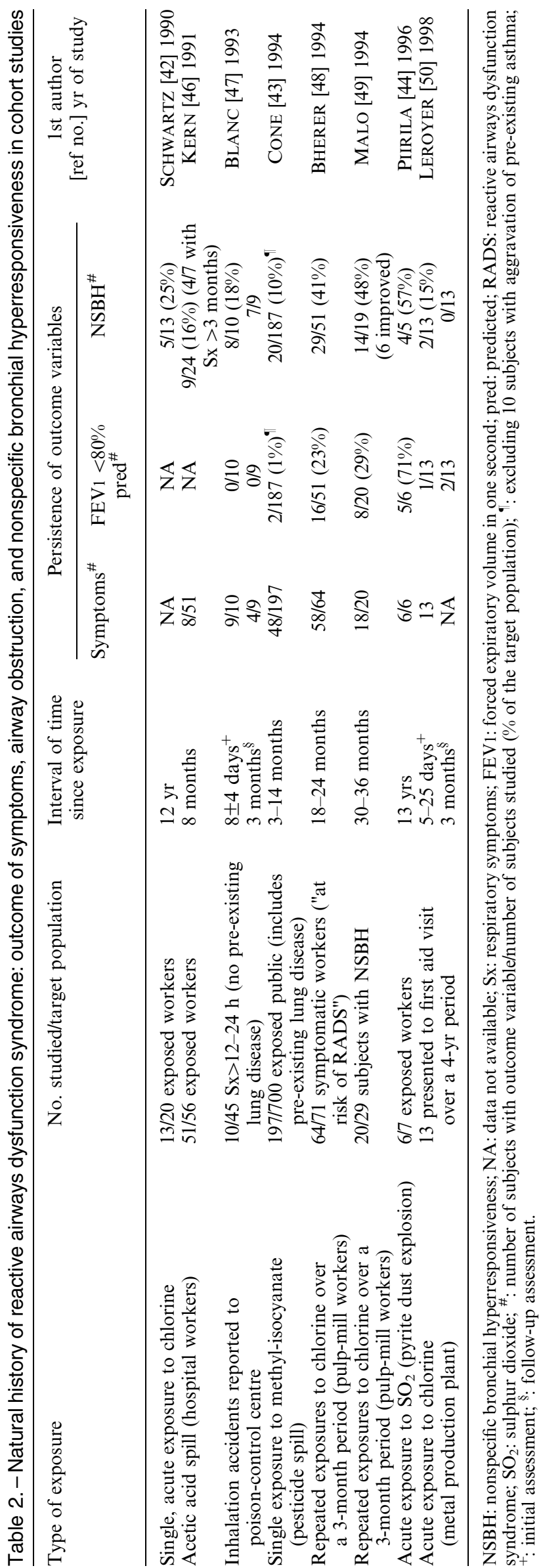

two of these workers demonstrated a significant increase in NSBH as compared with pre-exposure values. These changes in NSBH completely reversed within 3 months. Taken together, available studies suggest that the pattern of functional changes in irritant-induced OA may be remarkably similar to what has been described in subjects with immunological OA after cessation of exposure to causative sensitising agent, as NSBH can continue to improve for up to $3 \mathrm{yrs}$ following an inhalation accident. A single study suggested that most of the improvement in spirometric values occurs within the first year after acute exposure [44].

\section{Do working conditions have a significant impact on asthma regardless of the aetiology of the disease?}

Prevalence estimates of work-aggravated symptoms vary largely according to the populations studied, including $5-17 \%$ in general practice $[54,55], 16-31 \%$ in tertiary asthma clinics [56, 57], 20\% in patients hospitalised for asthma [58], and $20-57 \%$ in population-based surveys [59-62]. These findings provide convincing evidence that workplace exposure can cause exacerbation of respiratory symptoms in a substantial proportion of subjects with pre-existing or coincident asthma. In most of these studies, however, work-related changes in physiological indices of asthma were not investigated or, when they were investigated, objective changes could be documented only in a minority of the subjects experiencing asthma symptoms at work [57]. Thus, although widely used, terms such as "work-aggravated asthma" or "work-exacerbated asthma" most often refer to subjective worsening of asthma symptoms at work without objective lung function correlates. In addition, most controlled experiments among asthmatic volunteers have failed to demonstrate a physiologically relevant effect of exposure to irritant substances at permissible levels on airway calibre, level of NSBH, or airway inflammation [63-69], although some individuals may develop minimal changes in airway calibre $[64,65,68]$. Available data suggest that sulphur dioxide [70] and chlorine [71] can induce transient decrements in lung function in asthmatic subjects at lower levels than in those without NSBH. Moreover, it should be noted that several studies have identified considerable discordance between perceived symptoms and physiological parameters $[66,67]$, suggesting that lung-function tests alone may not adequately gauge the impact of exposure to irritant substances.

\section{What is the scope of work disability from work-related asthma in social and economic terms?}

The negative impact on the indirect cost of asthma can take many forms, including reduced workforce participation and employment rates, changes in employment or job duties as an adjustment to the asthmatic condition, asthma-related lost work days, and impaired work effectiveness while on the job. One cohort study of young adults showed that the rate of unemployment at the age of 23 yrs was slightly higher in those who reported a history of current or past asthma, independently from the severity of asthma [72]. In a random sample of 401 adult asthmatics, aged 18-50 yrs, seen by pulmonologists and allergy-immunologists in California, asthma was the reported cause of work cessation in $7 \%$ of the subjects [73]. In the study, work disability was related to asthma severity and job conditions [73]. When this cohort was assessed longitudinally and compared with an age-matched sample from the general population, however, asthma did not appear to affect employment status substantially, although 
individuals who were not working at the time of disease onset were less likely to be employed in subsequent years [74]. Demographic and employment characteristics were the strongest determinants of continuity of employment, while medical variables did not drive employment status.

Partial work disability, defined as any change in job duties or reduction in work hours due to asthma, has been described in $5 \%$ to $20 \%$ of adult asthmatics attending specialist clinics $[60,73,75]$. In a population-based study of Swedish adults [61], partial work disability due to respiratory problems was reported by $2 \%$ of subjects without asthma, $13 \%$ of subjects with self-reported asthma, and $22 \%$ of asthmatics with documented NSBH. A number of studies have indicated that asthmatic workers have a higher incidence of absenteeism $[59,76,77]$. In a recent USA survey, employer expenditures for asthmatic subjects was $\sim 2.5$ times higher than those for control nonasthmatic subjects [78]. Wage-replacement costs for lost work days accounted for almost as much as medical care expenses. Even when asthmatic subjects are on the job, a substantial proportion of them (ranging from 9-27\%) report a reduction in work effectiveness because of their condition $(60,76,77)$. Impairment in self-reported work effectiveness has been associated with more severe asthma, marked NSBH, and the presence of work-related respiratory symptoms [60].

\section{Immunological occupational asthma}

However potent the impact of asthma is in general, the work impact appears to be even more dramatic among the subset of adults with OA. Multiple studies conducted in various countries have shown that immunological OA is associated with considerable professional and financial consequences [22, 79-87]. As summarised in table 3, 25-38\% of subjects with OA suffer prolonged work disruption and $42-78 \%$ report a substantial loss of income [80-84, 87].

Financial consequences of $\mathrm{OA}$ are consistently more pronounced in workers who avoid further exposure to the causal agent [80, 84, 87]. This is likely to account for the finding that almost one third of workers with immunological
OA remain exposed to the causative agent (table 3 ). The medical consequences of exposure interventions have rarely been weighed against their financial impact. Only one prospective study has compared asthma severity, diseaserelated costs, and work-derived income after cessation or persistence of exposure to various agents causing OA [85]. About $40 \%$ of subjects who remained exposed had reduced levels of exposure to the causal agent. Complete avoidance of exposure to the causal agent resulted in a significant decrease in asthma severity and in healthcare expenses, but also in work-derived income, as compared with persistence of exposure [85]. In subjects with latex-induced OA [15], respiratory health outcomes improved similarly after reduction or cessation of exposure to airborne latex, whereas reduction of exposure resulted in a substantially lower professional and economic impact.

A number of vocational and sociodemographic factors adversely affect employment and socioeconomic status in workers with OA; these include unskilled jobs [80, 87], lower levels of education [84, 87], older age [81, 87], younger age [84], a lower number of economically-dependent subjects [81], and being employed in small-sized firms [84]. Interestingly, the clinical severity of asthma does not appear to be an important determinant of employment status in subjects with OA [79-85, 87].

The rate of unemployment among subjects with immunological OA seems higher than in the general population, although there is a need for further characterisation of the specific impact of $\mathrm{OA}$ as compared with nonwork-related asthma. In the only available study that compared immunological OA with nonwork-related asthma, the rate of unemployment was similar in the two groups, whereas a reduction of income was more frequently reported by subjects with OA $(62 \%)$ as compared with those with asthma unrelated to work $(38 \%)$ [83]. These two groups were not, however, matched for the severity of asthma and other relevant sociodemographic variables. Partial work disability, defined by any job change or work disruption due to asthma, occurred in $72 \%$ of Belgian subjects with ascertained $\mathrm{OA}$ and in $74 \%$ of Swedish subjects with claimed OA [88].

Table 3.-Socioeconomic consequences of occupational asthma

Country of study

\begin{tabular}{|c|c|c|c|c|c|c|}
\hline & \\
\hline & UK & British Columbia, Canada & Quebec, Canada & UK & France & Belgium \\
\hline 1st author [ref. no] & GANNON [80] & MARABINI [81] & DEWITTE [82] & CANNON [83] & AMEILLE [84] & LARBANOIS [87] \\
\hline Population & $112 / 140$ & $128 / 181$ & $134 / 211$ & $87 / 113$ & $209 / 257$ & $86 / 95$ \\
\hline Duration of follow-up yr & median: 1.4 & mean: $4.8 / 5.6$ & range: $2-5$ & 5 & mean: 3.1 & median: 3.3 \\
\hline Not working & 35 & 41 & 25 & 39 & 34 & 38 \\
\hline Unemployment & 20 & 38 & 8 & NA & 25 & 26 \\
\hline Early retirement & 15 & 4 & 16 & NA & 3 & 2 \\
\hline Chronic sick leave & 5 & NA & NA & NA & 6 & 10 \\
\hline Currently working & 65 & 58 & 75 & 61 & 66 & 62 \\
\hline Other job, same employer & 21 & NA & 31 & 21 & 18 & 15 \\
\hline New employer & 14 & NA & 36 & NA & 16 & 26 \\
\hline Retraining for another job & NA & NA & 8 & NA & NA & 0 \\
\hline Persistence of exposure & 30 & 38 & 0 & NA & 32 & 33 \\
\hline \multicolumn{7}{|l|}{ Loss of income } \\
\hline Exposed: & $44^{\#}$ & NA & NA & 55 & 46 & $42^{\#}$ \\
\hline Unexposed: & 74 & NA & NA & & & 78 \\
\hline Compensation & 24 & 70 & 100 & 28 & 49 & 87 \\
\hline $\begin{array}{l}\text { Loss of income offset by } \\
\text { compensation }\end{array}$ & NA & NA & NA & NA & 44 & 22 \\
\hline Job retraining program & NA & NA & 22 & NA & NA & 5 \\
\hline
\end{tabular}

Data are expressed as per cent of the total number of subjects included in the study unless otherwise stated. ${ }^{\#}$ : per cent of subjects included in each exposure category; ${ }^{\uparrow}$ : expressed as per cent of subjects who were compensated; NA: data not available. 


\section{Work-aggravated asthma}

The socioeconomic impact of work-aggravated asthma symptoms has received relatively little attention given the potential magnitude of the problem. The results of the few available studies show that, even in the absence of OA or irritant-induced asthma, work-aggravated asthma is associated with a considerable socioeconomic impact. CANNON et al. [83] found that the rate of unemployment was not different in work-exacerbated asthma $(31 \%)$, immunological OA $(39 \%)$, or "asthma unrelated to work" (32\%). In contrast, a reduction of income was reported more frequently by subjects with work-exacerbated asthma $(65 \%)$ and OA $(62 \%)$ than by those with "asthma unrelated to work" (38\%). In this study, however, all subjects were investigated for possible $\mathrm{OA}$ and the criteria used for diagnostic categorisation were not precisely defined. LARBANOIS et al. [87] compared the socioeconomic outcomes of subjects with ascertained immunological OA with those of subjects who experienced workaggravated asthma symptoms but failed to exhibit a positive response to specific inhalation challenges. The rates of unemployment $(46 \%)$ and income loss $(59 \%)$ in subjects with work-aggravated asthma symptoms did not differ significantly from those observed in subjects with OA $(38 \%$ and $62 \%$, respectively). Partial work disability, defined as any job change or work loss due to asthma, was slightly less common in subjects with work-aggravated asthma symptoms $(54 \%)$ than in those with OA $(72 \%)$.

\section{What is the clinician's role in reducing the respiratory health consequences of work-related asthma?}

\section{Immunological occupational asthma}

Targeting those factors that determine the persistence of asthma after removal from exposure is most relevant for improving respiratory health consequences of immunological OA. Indeed, making a reliable diagnosis of OA early after its onset could be the most straightforward way to reduce the long-term functional impairment resulting from OA. There is considerable evidence that $\mathrm{OA}$ remains largely underdiagnosed by healthcare providers. In a recent survey of asthmatic members of a health maintenance organisation in the USA, the work-relatedness of asthmatic symptoms was investigated by only $15 \%$ of general practitioners and $50 \%$ of allergists and chest physicians [55]. In addition, information from clinical studies, compensation statistics, and specific surveillance programs indicates a general lack of objective assessment of the work-relatedness of asthma [57, 89-92]. Once OA is suspected, the diagnosis should be promptly ascertained or excluded using the most reliable procedures, including monitoring of spirometry or peak expiratory flow at work and, where appropriate, specific inhalation challenges. As these diagnostic procedures require expertise and/or special equipment, they should be made more accessible through the formation of specialised diagnostic centres or through training a larger cadre of physicians with specific expertise in this area [92].

The impact of pharmacological therapy on the OA outcome remains uncertain. A retrospective study of subjects with OA found that treatment with inhaled steroids was not a significant determinant of changes in NSBH after withdrawal from exposure [18]. Only two studies have prospectively examined the effects of inhaled steroids in OA [93, 94]. These studies suggested that adding inhaled steroids to removal from exposure resulted in a small improvement in asthma symptoms, quality of life, peak expiratory flow rates [94], and
NSBH [93]. Worth noting is the fact that in one study, the beneficial effects of inhaled steroids appeared to be more pronounced when the treatment was started early after diagnosis [94].

\section{Irritant-induced asthma}

There are no controlled clinical data suggesting that irritant-induced asthma should be managed differently than any other form of asthma in terms of pharmacological treatment. Anecdotal reports indicate that early treatment with oral or inhaled steroids could exert a beneficial effect on the course of RADS [95-97], although prospective studies are required to determine the optimum dose and duration of treatment with inhaled steroids. When irritant-induced asthma has been provoked by acute exposure to agents that are also known to be sensitisers [36, 96, 98, 99], the possibility of specific bronchial hyperresponsiveness to these agents should also be taken into account [100, 101]. In most cases, however, workers with irritant-induced asthma are not, by definition, more reactive to the offending agent than other asthmatics. Accordingly, they can continue to work in the same environment, provided that levels of airborne irritants are kept below permissible levels at the workplace. Subjects with NSBH may, however, develop bronchial responses at lower levels of irritant substances, such as sulphur dioxide and chlorine [71], than it takes to provoke similar reactions in healthy subjects. The management of irritant-induced asthma may be further complicated by associated disorders, such as chronic rhinitis [102-104], perceived intolerance to multiple chemicals [105], hyperventilation syndrome [106], vocal cord dysfunction [107], and increased cough sensitivity [108], which can be associated with accidental exposure to irritant substances at work.

\section{Work-aggravated asthma}

The environmental and host factors that determine worsening of asthma symptoms at work should be further identified in order to improve the medical management of work-aggravated asthma symptoms. It has been proposed that work-related aggravation of asthma symptoms may reflect either exposure to higher-than-permissible levels of irritants at work, inappropriate treatment, or more severe underlying asthma [109]. Arguing against severity as a significant determinant, studies have observed that subjects with work-aggravated asthma show features indicating a milder asthma condition than what is found in those who do not experience worsening of symptoms at work [57] or those who have immunological OA [87]. Preliminary findings from a USA study comparing subjects with work-aggravated and occupational asthma suggest that subjects with workaggravated asthma are younger, include a higher proportion of females and non-Whites, and are more often exposed to inorganic dust [110].

Levels of these irritants should be kept to acceptable limits at work. It has to be recognised, however, that most of these limits have been derived from healthy populations or extrapolated from animal experiments, while the concentrations that trigger airway irritation can be different in susceptible populations such as those with asthma. The efficacy of anti-asthma medications in improving workrelated asthma symptoms and work performance warrants further prospective investigation using work-related symptoms and work-disability indices as endpoints. 


\section{To what extent do existing compensation and other social insurance schemes successfully address occupational asthma and work-aggravated asthma?}

Physiological impairment resulting from asthma can be quantified using the degree of airflow limitation, the level of $\mathrm{NSBH}$, and medications required to control symptoms, as recommended by the American Thoracic Society (ATS) [111]. Assessment of disability is much more complex, as it should take into account the impact that impairment may have in terms of function, such as the ability to work full time and without restriction of job duties or demands. Impairment does not lead to disability in a predictable manner. For instance, subjects with immunological OA should be considered completely and permanently disabled in terms of occupations that entail exposure to the sensitising agent that caused OA, even when their asthma demonstrates little physiological impairment without such exposure.

Objective assessment of the effectiveness of compensation systems, whether national or international, has seldom been carried out for occupational diseases in general and even less so for work-related asthma in particular. Available information (table 3) indicates that financial compensation for $\mathrm{OA}$ is currently inadequate in European countries, since about one third of subjects with OA remain exposed to the agent causing their asthma in order to avoid or minimise the adverse financial effects that would result from complete avoidance of exposure [80, 84, 87]. Even when assessment of impairment/ disability is based on the ATS recommendations, the loss of income is offset by awarded indemnities in only $22 \%$ of subjects with OA [87].

It appears that the rate of unemployment is lower among subjects with OA in Quebec $(25 \%)$ than in other countries (34 $41 \%$ ), despite removal from exposure of all affected workers (table 3). This lower rate of unemployment is coincident with a higher proportion of workers who benefit from professional retraining programs $(22 \%)$ and/or find another job with the same employer (31\% versus $15-21 \%)$. Extrapolating from this limited information, compensation schemes might be more effective to the extent that they can be redirected toward facilitating relocation into nonexposed jobs in the same company or retraining for other jobs rather than providing inadequate financial compensation. Furthermore, to be more equitable, compensation should ensure more appropriate income replacement when relocation or professional rehabilitation brings about a loss of earnings. Improving compensation for OA almost certainly requires that the cost and effectiveness of existing compensation systems be systematically evaluated.

A detailed review of international workers compensation schemes for OA and work-related asthma is far beyond the scope of this clinically-oriented summary. Differences among various systems are likely attributable to multiple factors, including economic forces, historical precedent, pattern of illness, cultural values, and political power balances. What is clear about compensation and asthma is that, by and large, all systems appear to address OA in a fairly heterogeneous manner.

\section{Conclusion and needs for future research}

Since the consequences of immunological occupational asthma in terms of respiratory health and socioeconomic status are now becoming better characterised, the major challenges for the clinicians and healthcare policy makers must shift from passive documentation of the problem toward the identification, implementation, and evaluation of strategies aimed at minimising these adverse impacts. Because the understanding of the natural history of irritant-induced asthma is more limited, the need for descriptive data is more pressing and prevention is an even greater challenge. Workaggravated asthma is an even more complex issue, since the very definition of what it entails continues to evolve as new data emerge. Clearly, understanding of the environmental and individual cofactors involved in the development and persistence of the various work-related asthma conditions should be enhanced in order to improve their management and reduce their health and economic impacts.

Acknowledgement. The authors thank L. Schubert for reviewing the manuscript.

\section{References}

1. Barnes PJ, Jonsson B, Klim JB. The costs of asthma. Eur Respir J 1996; 9: 636-642.

2. Weiss KB, Sullivan SD. The health economics of asthma and rhinitis. I. Assessing the economic impact. J Allergy Clin Immunol 2001; 107: 3-8.

3. Chan-Yeung M, Brooks S, Alberts W, et al. Assessment of asthma in the workplace. Chest 1995; 108: 1084-117.

4. Bernstein IL, Bernstein DI, Chan-Yeung M, Malo JL. Definition and classification of asthma. In: Bernstein IL, Chan-Yeung M, Malo JL, Bernstein DI, eds. Asthma in the Workplace. 2nd Edn. New York, Marcel Dekker Inc., 1999; pp. 1-3.

5. Blanc PD, Toren $\mathrm{K}$. How much adult asthma can be attributed to occupational factors? Am J Med 1999; 107: 580-587.

6. Venables KM, Topping MD, Nunn AJ, Howe W, Newman Taylor AJ. Immunologic and functional consequences of chemical (tetrachlorophthalic anhydride)-induced asthma after four years of avoidance of exposure. J Allergy Clin Immunol 1987; 80: 212-218.

7. Burge PS. Occupational asthma in electronics workers caused by colophony fumes: follow-up of affected workers. Thorax 1982; 37: 348-353.

8. Lozewicz S, Assoufi BK, Hawkins R, Taylor AJ. Outcome of asthma induced by isocyanates. Br J Dis Chest 1987; 81: 14-22.

9. Rosenberg N, Garnier R, Rousselin X, Mertz R, Gervais P. Clinical and socio-professional fate of isocyanate-induced asthma. Clin Allergy 1987; 17: 55-61.

10. Mapp CE, Corona PC, De Marzo N, Fabbri L. Persistent asthma due to isocyanates. A follow-up study of subjects with occupational asthma due to toluene diisocyanate (TDI). Am Rev Respir Dis 1988; 137: 1326-1329.

11. Pisati G, Baruffini A, Zedda S. Toluene diisocyanate induced asthma: outcome according to persistence or cessation of exposure. Br J Ind Med 1993; 50: 60-64.

12. Paggiaro PL, Vagaggini B, Dente FL, et al. Bronchial hyperresponsiveness and toluene diisocyanate. Long-term change in sensitized asthmatic subjects. Chest 1993; 103: 1123-1128.

13. Park HS, Nahm DH. Prognostic factors for toluene diisocyanate-induced occupational asthma after removal from exposure. Clin Exp Allergy 1997; 27: 1145-1150.

14. Chan-Yeung M, Lam S, Koener S. Clinical features and natural history of occupational asthma due to western red cedar (Thuja plicata). Am J Med 1982; 72: 411-415.

15. Vandenplas O, Jamart J, Delwiche JP, Evrard G, Larbanois A. Occupational asthma caused by natural rubber latex: outcome according to cessation or reduction of exposure. J Allergy Clin Immunol 2002; 109: 125-130.

16. Merget R, Reineke M, Rueckmann A, Bergmann EM, Schultze-Werninghaus G. Nonspecific and specific bronchial 
responsiveness in occupational asthma caused by platinum salts after allergen avoidance. Am J Respir Crit Care Med 1994; 150: 1146-1149.

17. Malo JL, Cartier A, Ghezzo H, Lafrance M, McCants M, Lehrer SB. Patterns of improvement in spirometry, bronchial hyperresponsiveness, and specific IgE antibody levels after cessation of exposure in occupational asthma caused by snow-crab processing. Am Rev Respir Dis 1988; 138: 807812.

18. Perfetti L, Cartier A, Ghezzo H, Gautrin D, Malo JL. Follow-up of occupational asthma after removal from or diminution of exposure to the responsible agent: relevance of the length of the interval from cessation of exposure. Chest 1998; 114: 398-403.

19. Grammer LC, Shaughnessy MA, Henderson J, et al. A clinical and immunologic study of workers with trimelliticanhydride- induced immunologic lung disease after transfer to low exposure jobs. Am Rev Respir Dis 1993; 148: 54-57.

20. Merget R, Schulte A, Gebler A, et al. Outcome of occupational asthma due to platinum salts after transferral to low-exposure areas. Int Arch Occup Environ Health 1999; 72: 33-39.

21. Piirila PL, Nordman H, Keskinen HM, et al. Long-term follow-up of hexamethylene diisocyanate-, diphenylmethane diisocyanate-, and toluene diisocyanate-induced asthma. Am J Respir Crit Care Med 2000; 162: 516-522.

22. Ross DJ, McDonald JC. Health and employment after a diagnosis of occupational asthma: a descriptive study. Occup Med (Lond) 1998; 48: 219-225.

23. Vandenplas O, Delwiche JP, Depelchin S, Sibille Y, Vande Weyer R, Delaunois L. Latex gloves with a lower protein content reduce bronchial reactions in subjects with occupational asthma caused by latex. Am J Respir Crit Care Med 1995; 151: 887-891.

24. Laoprasert N, Swanson MC, Jones RT, Schroeder DR, Yunginger JW. Inhalation challenge testing of latex-sensitive health care workers and the effectiveness of laminar flow HEPA-filtered helmets in reducing rhinoconjunctival and asthmatic reactions. J Allergy Clin Immunol 1998; 102: 9981004.

25. Slovak AJ, Orr RG, Teasdale EL. Efficacy of the helmet respirator in occupational asthma due to laboratory animal allergy (LAA). Am Ind Hyg Assoc J 1985; 46: 411-415.

26. Kongerud J, Rambjor O. The influence of the helmet respirator on peak flow rate in aluminum potroom. Am Ind Hyg Assoc J 1991; 52: 243-248.

27. Taivainen AI, Tukiainen HO, Terho EO, Husman KR. Powered dust respirator helmets in the prevention of occupational asthma among farmers. Scand J Work Environ Health 1998; 24: 503-507.

28. Obase Y, Shimoda T, Mitsuta K, Matsuse H, Kohno S. Two patients with occupational asthma who returned to work with dust respirators. Occup Environ Med 2000; 57: 62-64.

29. Ortega HG, Kreiss K, Schill DP, Weissman DN. Fatal asthma from powdering shark cartilage and review of fatal occupational asthma literature. Am J Ind Med 2002; 42: $50-54$.

30. Liss GM, Tarlo SM, Banks D, Yeung KS, Schweigert M. Preliminary report of mortality among workers compensated for work- related asthma. Am J Ind Med 1999; 35: 465-471.

31. Liss GM, Tarlo SM, Macfarlane Y, Yeung KS. Hospitalization among workers compensated for occupational asthma. Am J Respir Crit Care Med 2000; 162: 112-118.

32. Brooks SM, Weiss MA, Bernstein IL. Reactive airways dysfunction syndrome (RADS). Persistent asthma syndrome after high level irritant exposures. Chest 1985; 88: 376-384.

33. Alberts WM, do Pico GA. Reactive airways dysfunction syndrome. Chest 1996; 109: 1618-1626.

34. Gautrin D, Bernstein IL, Brooks SM. Reactive airways dysfunction syndrome or irritant-induced asthma. In: Bernstein IL, Chan-Yeung M, Malo JL, Bernstein DI, eds.
Asthma in the Workplace.. New York, Marcel Dekker Inc., 1999; pp. 565-593.

35. Vandenplas O, Malo JL. Definitions and types of workrelated asthma: a nosological approach. Eur Respir J 2003; 21: 706-712.

36. Tarlo SM, Broder I. Irritant-induced occupational asthma. Chest 1989; 96: 297-300.

37. Chan-Yeung M, Lam S, Kennedy SM, Frew A. Persistent asthma after repeated exposure to high concentrations of gases in pulpmills. Am J Respir Crit Care Med 1994; 149: $1676-1680$

38. Blanc PD, Galbo M, Hiatt P, Olson KR. Morbidity following acute irritant inhalation in a population-based study. JAMA 1991; 266: 664-669.

39. Sallie B, McDonald C. Inhalation accidents reported to the SWORD surveillance project 1990-1993. Ann Occup Hyg 1996; 40: 211-221.

40. Kaufman J, Burkons D. Clinical, roentgenologic, and physiologic effects of acute chlorine exposure. Arch Environ Health 1971; 23: 29-34.

41. Charan NB, Lakshminarayan S, Myers GC, Smith DD. Effects of accidental chlorine inhalation on pulmonary function. West J Med 1985; 143: 333-336.

42. Schwartz DA, Smith DD, Lakshminarayan S. The pulmonary sequelae associated with accidental inhalation of chlorine gas. Chest 1990; 97: 820-825.

43. Cone JE, Wugofski L, Balmes JR, et al. Persistent respiratory health effects after a metam sodium pesticide spill. Chest 1994; 106: 500-508.

44. Piirila PL, Nordman H, Korhonen OS, Winblad I. A thirteen-year follow-up of respiratory effects of acute exposure to sulfur dioxide. Scand J Work Environ Health 1996; 22: 191-196.

45. Conrad E, Lo W, deBoisblanc BP, Shellito JE. Reactive airways dysfunction syndrome after exposure to dinitrogen tetroxide. South Med J 1998; 91: 338-341.

46. Kern DG. Outbreak of the reactive airways dysfunction syndrome after a spill of glacial acetic acid. Am Rev Respir Dis 1991; 144: 1058-1064.

47. Blanc PD, Galbo M, Hiatt P, Olson KR, Balmes JR. Symptoms, lung function, and airway responsiveness following irritant inhalation. Chest 1993; 103: 1699-1705.

48. Bherer L, Cushman R, Courteau JP, et al. Survey of construction workers repeatedly exposed to chlorine over a three to six month period in a pulpmill: II. Follow up of affected workers by questionnaire, spirometry, and assessment of bronchial responsiveness 18 to 24 months after exposure ended. Occup Environ Med 1994; 51: 225-228.

49. Malo JL, Cartier A, Boulet LP, et al. Bronchial hyperresponsiveness can improve while spirometry plateaus two to three years after repeated exposure to chlorine causing respiratory symptoms. Am J Respir Crit Care Med 1994; 150: 1142-1145.

50. Leroyer C, Malo JL, Infante-Rivard C, Dufour JG, Gautrin D. Changes in airway function and bronchial responsiveness after acute occupational exposure to chlorine leading to treatment in a first aid unit. Occup Environ Med 1998; 55: 356-359.

51. Olin AC, Granung G, Hagberg S, et al. Respiratory health among bleachery workers exposed to ozone and chlorine dioxide. Scand J Work Environ Health 2002; 28: 117-123.

52. Gautrin D, Leroyer C, L'Archeveque J, Dufour JG, Girard D, Malo JL. Cross-sectional assessment of workers with repeated exposure to chlorine over a three year period. Eur Respir J 1995; 8: 2046-2054.

53. Gautrin D, Leroyer C, Infante-Rivard C, et al. Longitudinal assessment of airway caliber and responsiveness in workers exposed to chlorine. Am J Respir Crit Care Med 1999; 160: 1232-1237.

54. de Bono J, Hudsmith L. Occupational asthma: a community based study. Occup Med (Lond) 1999; 49: 217-219.

55. Milton DK, Solomon GM, Rosiello RA, Herrick RF. Risk 
and incidence of asthma attributable to occupational exposure among HMO members. Am J Ind Med 1998; 33: $1-10$.

56. Axon EJ, Beach JR, Burge PS. A comparison of some of the characteristics of patients with occupational and nonoccupational asthma. Occup Med (Lond) 1995; 45: 109-111.

57. Tarlo SM, Leung K, Broder I, Silverman F, Holness DL. Asthmatic subjects symptomatically worse at work: prevalence and characterization among a general asthma clinic population. Chest 2000; 118: 1309-1314.

58. Timmer S, Rosenman K. Occurrence of occupational asthma. Chest 1993; 104: 816-820.

59. Abramson MJ, Kutin JJ, Rosier MJ, Bowes G. Morbidity, medication and trigger factors in a community sample of adults with asthma. Med $J$ Aust 1995; 162: 78-81.

60. Balder B, Lindholm NB, Lowhagen $\mathrm{O}$, et al. Predictors of self-assessed work ability among subjects with recent- onset asthma. Respir Med 1998; 92: 729-734.

61. Blanc PD, Ellbjar S, Janson C, et al. Asthma-related work disability in Sweden. The impact of workplace exposures. Am J Respir Crit Care Med 1999; 160: 2028-2033.

62. Johnson AR, Dimich-Ward HD, Manfreda J, et al. Occupational asthma in adults in six Canadian communities. Am J Respir Crit Care Med 2000; 162: 2058-2062.

63. Harving H, Korsgaard J, Dahl R, Pedersen OF, Molhave L. Low concentrations of formaldehyde in bronchial asthma: a study of exposure under controlled conditions. $\mathrm{Br} \mathrm{Med} \mathrm{J}$ 1986; 293: 310.

64. Green DJ, Sauder LR, Kulle TJ, Bascom R. Acute response to $3.0 \mathrm{ppm}$ formaldehyde in exercising healthy nonsmokers and asthmatics. Am Rev Respir Dis 1987; 135: 1261-1266.

65. De Luca S, Caire N, Cloutier Y, Cartier A, Ghezzo H, Malo JL. Acute exposure to sawdust does not alter airway calibre and responsiveness to histamine in asthmatic subjects. Eur Respir J 1988; 1: 540-546.

66. Harving $\mathrm{H}$, Dahl R, Molhave L. Lung function and bronchial reactivity in asthmatics during exposure to volatile organic compounds. Am Rev Respir Dis 1991; 143: 751-754.

67. Beach JR, Raven J, Ingram $\mathrm{C}$, et al. The effects on asthmatics of exposure to a conventional water-based and a volatile organic compound-free paint. Eur Respir J 1997; 10: $563-566$

68. Vandenplas O, Delwiche JP, Staquet P, et al. Pulmonary effects of short-term exposure to low levels of toluene diisocyanate in asymptomatic subjects. Eur Respir J 1999; 13: 1144-1150.

69. Lemière C, Chaboillez S, Malo JL, Cartier A. Changes in sputum cell counts after exposure to occupational agents: what do they mean? J Allergy Clin Immunol 2001; 107: 10631068 .

70. Health effects of outdoor air pollution. Committee of the Environmental and Occupational Health Assembly of the American Thoracic Society. Am J Respir Crit Care Med 1996; 153: 3-50.

71. D'Alessandro A, Kuschner W, Wong H, Boushey HA, Blanc PD. Exaggerated responses to chlorine inhalation among persons with nonspecific airway hyperreactivity. Chest 1996; 109: 331-337.

72. Sibbald B, Anderson HR, McGuigan S. Asthma and employment in young adults. Thorax 1992; 47: 19-24.

73. Blanc PD, Cisternas M, Smith S, Yelin EH. Asthma, employment status, and disability among adults treated by pulmonary and allergy specialists. Chest 1996; 109: 688-696.

74. Yelin E, Henke J, Katz PP, Eisner MD, Blanc PD. Work dynamics of adults with asthma. Am J Ind Med 1999; 35: 472-480.

75. Mancuso C, Charlson M. Adverse work outcomes due to asthma. Am J Respir Crit Care Med 2002; 165: A526.

76. McClellan VE, Garrett JE. Asthma and the employment experience. $N Z$ Med $J$ 1990; 103: 399-401.

77. Blanc PD, Trupin L, Eisner M, et al. The work impact of asthma and rhinitis: findings from a population-based survey. J Clin Epidemiol 2001; 54: 610-618.

78. Birnbaum HG, Berger WE, Greenberg PE, et al. Direct and indirect costs of asthma to an employer. J Allergy Clin Immunol 2002; 109: 264-270.

79. Venables KM, Davison AG, Newman Taylor AJ. Consequences of occupational asthma. Respir Med 1989; 83: $437-440$

80. Gannon PF, Weir DC, Robertson AS, Burge PS. Health, employment, and financial outcomes in workers with occupational asthma. Br J Ind Med 1993; 50: 491-496.

81. Marabini A, Dimich-Ward H, Kwan SY, Kennedy SM, Waxler-Morrison N, Chan-Yeung M. Clinical and socioeconomic features of subjects with red cedar asthma. A follow-up study. Chest 1993; 104: 821-824.

82. Dewitte JD, Chan-Yeung M, Malo JL. Medicolegal and compensation aspects of occupational asthma. Eur Respir $J$ 1994; 7: 969-980.

83. Cannon J, Cullinan P, Newman Taylor A. Consequences of occupational asthma. BMJ 1995; 311: 602-603.

84. Ameille J, Pairon JC, Bayeux MC, et al. Consequences of occupational asthma on employment and financial status: a follow-up study. Eur Respir J 1997; 10: 55-58.

85. Moscato G, Dellabianca A, Perfetti L, et al. Occupational asthma: a longitudinal study on the clinical and socioeconomic outcome after diagnosis. Chest 1999; 115: 249-256.

86. Gassert TH, Hu H, Kelsey KT, Christiani DC. Longterm health and employment outcomes of occupational asthma and their determinants. J Occup Environ Med 1998; 40: 481-491.

87. Larbanois A, Jamart J, Delwiche JP, Vandenplas O. Socieconomic outcome of subjects experiencing asthma symptoms at work. Eur Respir J 2002; 19: 1107-1113.

88. Andersson EB, Toren K. Consequences of reported occupational asthma. Eur Respir J 2001; 18: Suppl. 33, 508s.

89. Liss GM, Tarlo SM, Banks DE. Evidence for occupational asthma among compensation claimants at a polyurethane utilizing facility. Can J Public Health 1996; 87: 401-403.

90. Rosenman KD, Reilly MJ, Kalinowski DJ. A state-based surveillance system for work-related asthma. J Occup Environ Med 1997; 39: 415-425.

91. Kopferschmitt-Kubler MC, Ameille J, Popin E, et al. Occupational asthma in France: a 1-yr report of the observatoire National de Asthmes Professionnels project. Eur Respir J 2002; 19: 84-89.

92. Ortega HG, Weissman DN, Carter DL, Banks D. Use of specific inhalation challenge in the evaluation of workers at risk for occupational asthma: a survey of pulmonary, allergy, and occupational medicine residency training programs in the United States and Canada. Chest 2002; 121: 1323-1328.

93. Maestrelli P, De Marzo N, Saetta M, Boscaro M, Fabbri LM, Mapp CE. Effects of inhaled beclomethasone on airway responsiveness in occupational asthma. Placebo-controlled study of subjects sensitized to toluene diisocyanate. Am Rev Respir Dis 1993; 148: 407-412.

94. Malo JL, Cartier A, Côté J, et al. Influence of inhaled steroids on recovery from occupational asthma after cessation of exposure: an 18-month double-blind crossover study. Am J Respir Crit Care Med 1996; 153: 953-960.

95. Chester EH, Kaimal J, Payne CB, Jr., Kohn PM. Pulmonary injury following exposure to chlorine gas. Possible beneficial effects of steroid treatment. Chest 1977; 72: 247-250.

96. Lemière C, Malo JL, Boulet LP, Boutet M. Reactive airways dysfunction syndrome induced by exposure to a mixture containing isocyanate: functional and histopathologic behaviour. Allergy 1996; 51: 262-265.

97. Lemière C, Malo JL, Boutet $\mathrm{M}$. Reactive airways dysfunction syndrome due to chlorine: sequential bronchial biopsies and functional assessment. Eur Respir J 1997; 10: 241-244.

98. Frans A, Pahulycz C. Transient syndrome of acute irritation of the bronchi induced by single and massive inhalation of phthalic anhydride. Rev Pneumol Clin 1993; 49: 247-251. 
99. Luo JC, Nelsen KG, Fischbein A. Persistent reactive airway dysfunction syndrome after exposure to toluene diisocyanate. Br J Ind Med 1990; 47: 239-241.

100. Boulet LP. Increases in airway responsiveness following acute exposure to respiratory irritants. Reactive airway dysfunction syndrome or occupational asthma? Chest 1988; 94: 476-481.

101. Leroyer C, Perfetti L, Cartier A, Malo JL. Can reactive airways dysfunction syndrome (RADS) transform into occupational asthma due to "sensitisation" to isocyanates? Thorax 1998; 53: 152-153.

102. Leroyer C, Malo JL, Girard D, Dufour JG, Gautrin D. Chronic rhinitis in workers at risk of reactive airways dysfunction syndrome due to exposure to chlorine. Occup Environ Med 1999; 56: 334-338.

103. Demeter SL, Cordasco EM, Guidotti TL. Permanent respiratory impairment and upper airway symptoms despite clinical improvement in patients with reactive airways dysfunction syndrome. Sci Total Environ 2001; 270: 49-55.

104. Shusterman D, Solomon C, Balmes J, Blanc P. Chlorine exposure and the upper respiratory tract. Eur Respir J 2002; 19: $381-382$.
105. Meggs WJ. RADS and RUDS--the toxic induction of asthma and rhinitis. $J$ Toxicol Clin Toxicol 1994; 32: 487501.

106. Shusterman D, Balmes J, Cone J. Behavioral sensitization to irritants/odorants after acute overexposures. J Occup Med 1988; 30: 565-567.

107. Perkner JJ, Fennelly KP, Balkissoon R, et al. Irritantassociated vocal cord dysfunction. J Occup Environ Med 1998; 40: 136-143

108. Gordon SB, Curran AD, Turley A, et al. Glass bottle workers exposed to low-dose irritant fumes cough but do not wheeze. Am J Respir Crit Care Med 1997; 156: 206210.

109. Malo JL, Chan-Yeung M. Comment on the editorial "occupational asthma: prevention by definition". Am J Ind Med 1999; 35: 207-208.

110. Goe JK, Henneberger PK, Reilly MJ, et al. A descriptive study of work-aggravated asthma. Am J Respir Crit Care Med 2002; 165: A526.

111. American Thoracic Society. Guidelines for the evaluation of impairment/disability in patients with asthma. Am Rev Respir Dis 1993; 147: 1056-1061. 